University of Nebraska - Lincoln

DigitalCommons@University of Nebraska - Lincoln

USDA National Wildlife Research Center - Staff Publications
U.S. Department of Agriculture: Animal and Plant Health Inspection Service

October 2006

\title{
West Nile Virus Antibody Prevalence in Red-Winged Blackbirds (Agelaius phoeniceus) from North Dakota, USA (2003-2004)
}

\author{
Heather Sullivan \\ USDA/APHIS/WS National Wildlife Research Center, Heather.Sullivan@aphis.usda.gov \\ George M. Linz \\ USDA/APHIS/WS National Wildlife Research Center, george.m.linz@aphis.usda.gov \\ Larry Clark \\ USDA/APHIS/WS National Wildlife Research Center, larry.clark@aphis.usda.gov \\ Mo Salman \\ USDA/APHIS/WS National Wildlife Research Center
}

Follow this and additional works at: https://digitalcommons.unl.edu/icwdm_usdanwrc

Part of the Environmental Sciences Commons

Sullivan, Heather; Linz, George M.; Clark, Larry; and Salman, Mo, "West Nile Virus Antibody Prevalence in Red-Winged Blackbirds (Agelaius phoeniceus) from North Dakota, USA (2003-2004)" (2006). USDA National Wildlife Research Center - Staff Publications. 447.

https://digitalcommons.unl.edu/icwdm_usdanwrc/447

This Article is brought to you for free and open access by the U.S. Department of Agriculture: Animal and Plant Health Inspection Service at DigitalCommons@University of Nebraska - Lincoln. It has been accepted for inclusion in USDA National Wildlife Research Center - Staff Publications by an authorized administrator of DigitalCommons@University of Nebraska - Lincoln. 


\title{
Research Paper
}

\section{West Nile Virus Antibody Prevalence in Red-Winged Blackbirds (Agelaius phoeniceus) from North Dakota, USA (2003-2004)}

\author{
HEATHER SULLIVAN,${ }^{1,2}$ GEORGE LINZ, ${ }^{3}$ LARRY CLARK $^{1}$ and MO SALMAN ${ }^{2}$
}

\begin{abstract}
This study was designed to explore the role that red-winged blackbirds (Agelaius phoeniceus) may have played in disseminating West Nile virus (WNV) across the United States. Using enzyme-linked immunosorbent assays designed to detect WNV antibodies in avian species we were able to determine the WNV antibody prevalence in a cohort of red-winged blackbirds in central North Dakota in 2003 and 2004. The peak WNV antibody prevalence was $22.0 \%$ in August of 2003 and $\mathbf{1 8 . 3} \%$ in July of 2004. The results of this study suggest that red-winged blackbird migratory populations may be an important viral dispersal mechanism with the ability to spread arboviruses such as WNV across the United States. Key Words: West Nile virus-Red-winged blackbirds-North Dakota. Vector-Borne Zoonotic Dis. 6, 305-309.
\end{abstract}

\section{INTRODUCTION}

$\mathbf{W}$ Est Nile Virus (WNV) emerged in North America in New York City during the summer of 1999 . To date, 16,706 positive human cases from 49 states and 666 human fatalities have been reported to the Centers for Disease Control and Prevention (CDC) in the United States (Smith 2005). In addition to human cases, WNV outbreaks have resulted in the deaths of 47,923 birds from 48 states (Smith, 2005). More than 285 wild, exotic, and captive bird species have been reported to the CDC WNV avian mortality database (Smith 2005).

The WNV impact on avian populations might be significantly underestimated because most of the dead bird cases are found in areas with high human activity, and the birds tend to be large in size and, thus, are easily detected. Additionally, some communities ceased WNV testing in dead birds after a few positive cases had been confirmed and began mosquito control in the affected areas. Thus, the ecological consequences of WNV in bird population within the United States might be slow to emerge.

In this paper, we describe the results of a serological survey of WNV-specific antibody prevalence in central North Dakota's migratory population of red-winged blackbirds in 2003 and 2004. We selected red-winged blackbirds as our avian model because of their abundance and wide distribution throughout the United States, and because their ecology includes

\footnotetext{
${ }^{1}$ USDA National Wildlife Research Center, Fort Collins, Colorado.

${ }^{2}$ Animal Population Health Institute, College of Veterinary Medicine and Biomedical Sciences, Colorado State University, Environmental Health Department, Fort Collins, Colorado.

${ }^{3}$ USDA National Wildlife Research Center, Bismarck, North Dakota.
} 
known risk factors in the maintenance and amplification of WNV. Our objective was to determine what role the red-winged blackbirds migratory population may have played in disseminating the virus across the United States.

WNV in humans and equines began to surface in North Dakota in the fall of 2002 as well as Saskatchewan and Manitoba, Canada, where migratory red-winged blackbirds have established breeding sites. With this preliminary information, it was suspected that the numbers of human, equine, and dead bird cases would increase the following year. We collected whole blood samples from red-winged blackbirds in Stutsman, Kidder, and Burleigh Counties in North Dakota, because they had sufficient redwinged blackbird populations for repeated sampling in 2003 and 2004. Additionally, the sites are located along the Mississippi and Central flyway which Red-winged blackbirds and other avian species utilize during spring and fall migration. These sites are described as marsh habitat and are within a half mile of homes and horse stables.

\section{METHODS}

Red-winged blackbirds were taken with shotguns every 3 weeks from May through September 2003 from Stutsman and Burleigh counties $(n=301)$ and from May through August 2004 from Stutsman, Burleigh, and Kidder counties $(n=362)$. Biologists immediately collected red-winged blackbird's they had shot and placed a Nobuto ${ }^{\circledR}$ blood strip on the wound and collected approximately $0.1 \mathrm{~mL}$ of blood. The blood strips were allowed to air dry, labeled, placed in a small manila envelope, and stored at $4^{\circ} \mathrm{C}$ until they were shipped to the USDA's National Wildlife Research Centers Disease Laboratory (Fort Collins, CO), where they were analyzed for WNV-specific antibodies.

Nobuto ${ }^{\circledR}$ blood strips were extracted following the methods described by the manufacturer (Toyo Roshi Kaisha, Tokyo, Japan). Nobuto ${ }^{(1)}$ extracts were analyzed for WNV-specific antibodies using the epitope-blocking enzymelinked immunoassay (bELISA), which detects both IgM and IgG WN antibodies and indirect
ELISA (iELISA), which detects IgG WN antibodies only, as described by Sullivan et al. (unpublished data). The iELISA was performed in order to distinguish between a recent exposure versus an older exposure. The iELISA only detects IgG antibodies that are produced by the immune system shortly after the $\operatorname{Ig} M$ antibody response. The bELISA procedures have been described by Blitvich et al. (2003). The iELISA procedure was described by Ebel et al. (2002). WNV-positive and WNV-negative antibody controls were obtained from the Weld County, Colorado, sentinel chicken flocks. Whole blood was collected via venipuncture from chickens and confirmed as positive or negative for WNV-specific antibodies. Both positive and negative controls were included in every ELISA to verify reagent response to test conditions.

\section{RESULTS}

In 2003, the WNV IgM and IgG antibody prevalence in red-winged blackbirds was $2.8 \%$ $(n=71)$ in May, and peaked in August at $22.0 \%$ $(n=41)$ using the bELISA (Fig. 1). In August, $7.3 \%$ of the $22.0 \%$ total WNV antibody prevalence tested positive for IgG antibodies using the iELISA (Fig. 2). In September 2.2\% of the $11.1 \%$ total WNV antibody prevalence tested positive for IgG antibodies using the iELISA (Fig. 2).

During the WNV antibody survey in 2003, the red-winged blackbird seroprevalence appeared to correspond with the reported human cases in North Dakota (Fig. 3). The North

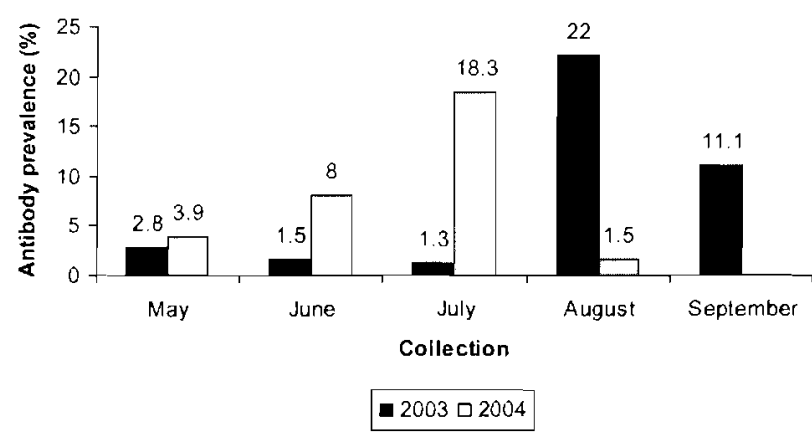

FIG. 1. West Nile virus-specific antibody prevalence (\%) in red-winged blackbirds, North Dakota, 2003-2004. 


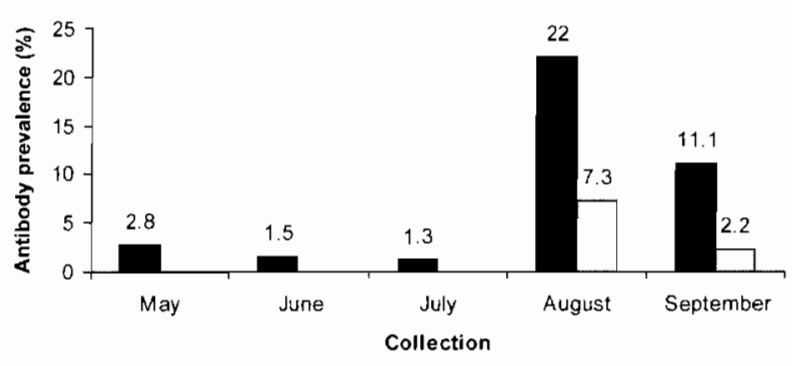

- $\lg M$ and $\lg G$ WNv Antibodies $\square \lg G$ WNv Antibodies

FIG. 2. West Nile virus IgM and IgG antibody prevalence versus $\mathrm{IgG}$ antibody prevalence only (\%) in redwinged blackbirds, 2003.

Dakota dead bird cases occurred approximately 1 month prior to the increase in WNV antibody prevalence in red-winged blackbirds. However, these dead bird cases would have been confirmed positive for virus which occurs just after becoming infected but prior to developing an immune response. The dead bird cases may also correspond with the increased red-winged blackbird antibody prevalence had the dead birds survived long enough to produce a detectable immune response.

In 2004, the WNV IgM and IgG antibody prevalence was $3.9 \%(n=76)$ in May and peaked in July at $18.3 \%(n=142)$ using the bELISA (Fig. 1). No samples were collected during the month of September. All of the samples that tested positive for WNV antibodies tested negative for WNV IgG antibodies using the iELISA. In 2004, the red-winged blackbird WNV antibody prevalence emerged prior to the North Dakota human and dead bird cases (Fig. 4).

\section{DISCUSSION}

The data collected shows that WNV does circulate throughout red-winged blackbird populations; therefore, they could have played an integral role in disseminating $\mathrm{WNV}$ across the United States. Red-winged blackbirds are abundant ( $\sim 150$ million in North America), and their migratory movements appear to correspond to the North American expansion of WNV (McLean 2002). In North Dakota, the late summer red-winged blackbird population is approximately 15 million (Homan 2004). If the peak WNV-specific antibody prevalence in August of 2003 was $22.0 \%$, then approximately 2 million Red-winged blackbirds could have been infected by WNV. This is an estimate based solely upon the assumption that mortality does not occur in the red-winged blackbird population after a WNV infection. However, even if 50\% mortality occurred, approximately 1 million red-winged blackbirds could have been infected. In an experimental study, Komar (2003) demonstrated that a red-winged blackbird could amplify virus at detectable and infectious levels (from $10^{5.5}$ to $10^{9.0}$ plaque-forming units [pfu] $\mathrm{mL}$ serum, with a threshold level of infectious viremia $10^{50} \mathrm{pfu} / \mathrm{mL}$ serum) for up to 3 days. A red-winged blackbird can travel great distances, up to $1,200 \mathrm{~km}$ between the breeding season and winter (Dolbeer 1982). The red-winged blackbirds only travel during the day and roost from dusk through dawn, at which time there is a greater likelihood of being bitten by an infected mosquito (Yasukawa 1995). If clinical signs are not present or do not affect a red-winged blackbird's normal movement or migration, and there is a sufficient amount of virus circulating in their system to be capable of infecting a mosquito, they could potentially transmit WNV across a significant distance within 3 days during migration. WNV morbidity data in red-winged blackbirds is unknown; however, other studies indicate that a WNV infection in European starlings (Sturnus vulgaris) does not appear to encumber their normal behavior (C.A. Smeraski, personal communication, 2005). Although the above men-

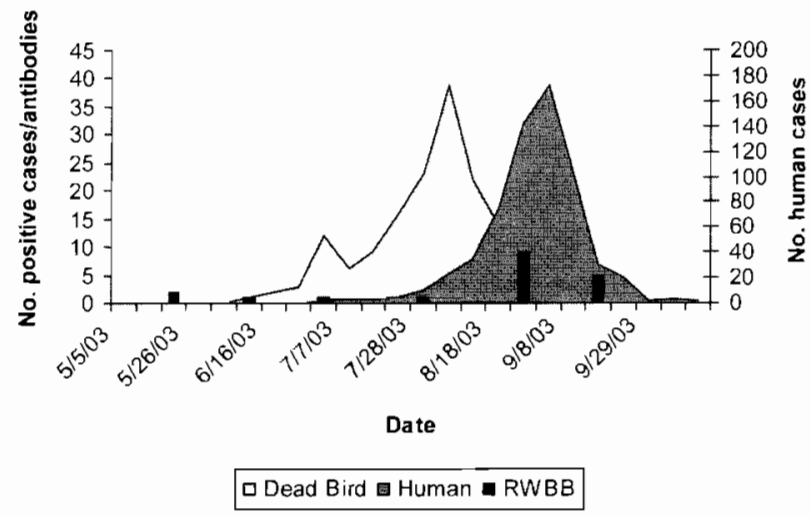

FIG. 3. Comparison of West Nile virus-positive cases for humans, dead birds, and red-winged blackbirds, North Dakota, 2003, as a function of time. 


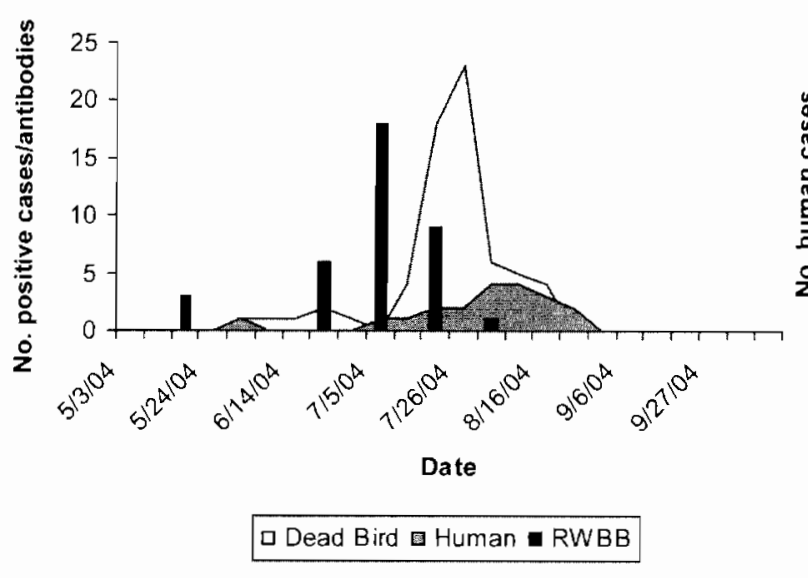

FIG. 4. Comparison of West Nile virus-positive cases for humans, dead birds, and red-winged blackbirds, North Dakota, 2004, as a function of time.

tioned estimates are substantial and are based on several assumptions, these estimates are not unrealistic.

The ecology of red-winged blackbirds includes known risk factors in the maintenance and amplification of WNV; for example, these birds appear to be host competent because they are able to circulate high levels of virus $\left(10^{9.0}\right.$ $\mathrm{pfu} / \mathrm{mL}$ serum) with a low mortality (Komar 2003). red-winged blackbirds belong to the Passerine order, where WNV mortality rates have been the highest, but they do not appear to be as susceptible as other Passerines such as the American Crow and Blue Jay (Komar 2003). The above mentioned study, however, had a limited sample size, and mortality estimates for red-winged blackbirds should be further studied. They also utilize wetlands during migration and breeding where mosquito populations are abundant.

In 2003, the WNV-specific antibody prevalence in red-winged blackbirds was observed from August through September. This could be explained by the start of the red-winged blackbird's southern migration from established breeding grounds located north of the study area. Perhaps the red-winged blackbirds that had developed an immune response had begun to move south into the area where the study sites were located and continued to move south, which is indicated by the drop-off in WNV antibody prevalence (Fig. 1). According to Dr. Linz (personal communication, 2005) there are no overwintering red-winged black- bird populations in and around the study sites in North Dakota; therefore, the birds in this study are migratory. There are some resident breeding birds still in the area in August and September. However, because the red-winged blackbird WNV antibody prevalence corresponded to the human and dead bird cases, this simply could have been the time in which WNV transmission occurred in this particular area.

In 2004, a few WNV infections in red-winged blackbirds appeared in early May. Most of the WN activity in red-winged blackbirds took place during the breeding season from late June to early August (Fig. 4). The WNV antibody prevalence in red-winged blackbirds occurred prior to the dead bird and human cases, which is in contrast with 2003 data. This is most likely due to the establishment of WNV in the mosquito vectors and the red-winged blackbird population. Scientists have speculated on the presence of an overwintering mechanism that allows the virus to re-emerge in early spring prior to the influx of mosquitoes in some of the more temperate climates (Goddard 2003). Also in contrast to the 2003 data, WNV antibody prevalence in red-winged blackbirds and the number of WNV dead bird cases drastically decreased in August (Fig. 4). Not only was August 2004 an abnormally dry month, but during the week of August 16th, North Dakota experienced a frost; both of these factors could reduce the amount of transmission occurring due to a reduction in the vector population (NDASS 2004).

Dead bird cases only provide information concerning recently WNV infected birds. We caution that this study exhibits a response to WNV in a population of birds that survived the initial infection and not of the population as a whole because morbidity and mortality data for red-winged blackbirds is insufficient.

Experimental WNV infection studies could provide information that would enable scientists to predict the physiological response to WNV by red-winged blackbirds. For instance, the time of initial infection could be estimated as well as the time required for the red-winged blackbird's immune system to respond to the virus and begin producing antibodies. Whether the virus affects the speed or distance of a redwinged blackbird's normal movement and mi- 
gration could also be determined by means of an experimental infection study. Red-winged blackbird mortality data is limited in a surveillance study because these birds spend most of their time in marsh habitat which would prove difficult for dead birds to be found. An experimental infection study could answer this question as well. This type of study would also allow serum samples to be collected from the red-winged blackbirds in order to confirm positive results using the gold standard, plaque reduction neutralization test (PRNT), which requires undiluted serum samples. However, we are confident the results obtained using the Nobuto ${ }^{\circledR}$ extracts are relatively analogous to serum samples for two reasons. According to Blitvich et al. (2003), the bELISA was considered "superior in sensitivity" to the PRNT, with the exception that the bELISA would also detect non-neutralizing antibodies, whereas the PRNT would only detect neutralizing antibodies. The second reason is due to information gathered from a recent study where concordance between two blood collection methods, Nobuto ${ }^{\circledR}$ extracts versus sera samples, was observed (kappa $=0.62,95 \%$ CI 0.36-0.88, $p<$ 0.001 ; kappa $=0.4-0.75$ has been characterized as fair to good agreement beyond chance) when using the bELISA (unpublished data).

Further studies could enable scientists to answer several key questions regarding the relationship between red-winged blackbird ecology and WNV. The red-winged blackbird migratory population may be an important viral dispersal mechanism that deserves further study. By assessing the risks involved with the dynamics of this relationship, we may be able to better predict, prevent, and control future epidemics that incorporate competent and abundant hosts such as the red-winged blackbird and the movement of emerging arboviruses throughout North America.

\section{ACKNOWLEDGMENTS}

I thank the committed Wildlife Service personnel, including Jeff Homan, Ryan Wimberly and Ryan Powers for their assistance in the collection of the numerous samples and enduring long, warm North Dakota summer days two years in a row. I also thank Kevin Bentler a Lab- oratory Biologist at the National Wildlife Research Center in the Wildlife Disease Program, for all his hard work and assistance in the laboratory.

\section{REFERENCES}

Blitvich, B, Marlenee, NL, Hall, RA, et al. Epitope-blocking enzyme-linked immunosorbent assays for the detection of serum antibodies to West Nile virus in multiple avian species. J Clin Microbiol 2003; 41:1041-1047.

Dolbeer, RA. Migration patterns for sex and age classes of blackbirds and starlings. J Field Ornithol 1982; 53:28-46.

Ebel, GD, Dupuis II, AP, Nicholas, D, et al. Detection by enzyme-linked immunosorbent assay of antibodies to West Nile virus in birds. Emerg Infect Dis 2002; 8:979-982

Goddard, LB, Roth, AE, Reisen, WK, et al. Vertical transmission of West Nile virus by three California Culex (Diptera: Culicidae) species. J Med Entomol 2003; 40:743-746.

Homan, JH, Penry, LB, Linz, GM. Linear Modeling of Blackbird Populations Breeding in Central North America. National Sunflower Association Research Forum Papers. Fargo, ND: National Sunflower Association, 2004.

Komar, N, Langevin, S, Hinten, S, et al. Experimental infection of North American birds with the New York 1999 strain of West Nile virus. Emerg Infect Dis 2003; 9:311-322.

McLean, RG, Guptill, SC. Use of bird banding information to investigate disease, safety, and economic issues of birds and their interactions with humans: the history of bird banding. Presented at the Third North American Ornithological Conference on Celebrating 100 Years of bird Banding in North America, New Orleans, 2002.

NDASS (North Dakota Agricultural Statistics Service). North Dakota Agricultural Statistics (2004). Fargo, ND: North Dakota State University, 2005.

Smith, T. National West Nile virus surveillance summary, United States, 2004. Presented at the $6^{\text {th }}$ National Conference on West Nile Virus, San Jose, 2005.

Yasukawa, K, Searcy, WA. Red-winged blackbird (Agelaius phoeniceus). In: Poole, A, Gill, F, eds. The Birds of North America, No. 184. Philadelphia: Academy of Natural Sciences, and Washington, DC: American Ornithologists' Union; 1995:1-27.

Address reprint requests to: Heather Sullivan

USDA National Wildlife Research Center Wildlife Disease Program 4101 LaPorte Ave. Fort Collins, CO 80521

E-mail: Heather.Sullivan@aphis.usda.gov 